\title{
New Subtribes of the Lactuceae (Asteraceae)
}

\author{
Kåre Bremer \\ Department of Systematic Botany, Uppsala University, \\ Villavägen 6, S-752 36 Uppsala, Sweden
}

ABSTRact. The subtribal classification of tribe Lactuceae is emended to include three new subtribes: Catananchinae (Mediterranean; Catananche, Hymenonema, Rothmaleria), Malacothricinae (North American; Anisocoma, Atrichoseris, Calycoseris, Glyptopleura, Malacothrix, Munzothamnus, Pinaropappus), and Sonchinae (almost worldwide; Sonchus, Launaea, and their immediate relatives).

In a forthcoming book on the cladistics and classification of the Asteraceae (Bremer, in press), a revised tribal and subtribal classification is presented. In the tribe Lactuceae, this necessitates description of three new subtribes. The most recent subtribal classification of the Lactuceae is by Stebbins (1953), who divided the Lactuceae into eight subtribes and a number of subgroups:

Scolyminae Lessing

Cichoriinae O. Hoffmann

Tolpis-Arnoseris generic group

Catananche-Hymenonema generic group

Microseridinae Stebbins

Stephanomeriinae Stebbins

Stephanomeria generic group

Malacothrix generic group

Dendroseridinae Bentham \& Hooker f.

Scorzonerinae Dumortier

Leontodontinae O. Hoffmann (= Hypochaeridinae Lessing)

Crepidinae Dumortier

Dubyaea-Soroseris line

Launaea-Sonchus line

Hieracium-Andryala line

Prenanthes-Lactuca line

Youngia-Ixeris line

Crepis line

This classification was modified by Jeffrey (1966), but he did not recognize any formal subtribes. I propose to combine the Tolpis-Arnoseris and Hieracium-Andryala groups as a separate subtribe Hieraciinae (Bremer, in press). This is in agreement with Jeffrey (1966), who classified these genera together in his Tolpis subgroup. I will also remove Stebbins's Prenanthes-Lactuca line to a separate subtribe Lactucinae (Bremer, in press). Both sub- tribal names, Hieraciinae Dumortier and Lactucinae Dumortier, are already available (cf. Solbrig, 1963). My further reclassification of the Lactuceae includes three new subtribes based on the Catananche-Hymenonema, Malacothrix, and Launaea-Sonchus groups.

Catananche, Hymenonema, and Rothmaleria are regarded as isolated genera in the Lactuceae. They share involucral bracts with scarious margins, bristly-scaly to paleate receptacles, and a pappus of few large scales usually prolonged into stiff bristles. Catananche is circum-Mediterranean in distribution, Hymenonema occurs in Greece, and Rothmaleria in Spain. In a cladistic analysis of 23 genera of the Lactuceae and 23 morphological characters (Bremer, in press), the three genera Catananche, Hymenonema, and Rothmaleria consistently form a monophyletic group, occupying a phylogenetically basal position as sister group to most of the tribe. They are described here as a new subtribe, Catananchinae.

Stebbins (1953) described the subtribe Stephanomeriinae. He noted that the genera he included are rather diverse in habit and technical characters, and that there is no single diagnostic character for the subtribe. The Stephanomeriinae are entirely North American in distribution, and most of the species differ from most Old World Lactuceae by their echinate pollen grains. Stebbins divided his Stephanomeriinae into two rather different groups, the Stephanomeria group and the Malacothrix group. The latter comprises mostly few-branched, sometimes scapose annual herbs (Anisocoma, Atrichoseris, Calycoseris, Glyptopleura, Malacothrix; cf. Williams, 1957). They frequently have scariousmargined involucral bracts and bristly-scaly receptacles, and are in these features, but not in others, similar to the Catananchinae. The perennial Pinaropappus with a paleate receptacle is somewhat aberrant, but presumably related to Malacothrix (Jeffrey, 1966). The shrubby Munzothamnus (Raven, 1963), originally described as a species of Stephanomeria, is difficult to classify but is possibly more closely related to Malacothrix than to Stephanomeria and hence is possibly a specialized representative of the Malacothrix group. The position 
of Munzothamnus must be regarded as tentative. In my cladistic analysis of the Lactuceae (Bremer, in press), both Malacothrix and Stephanomeria were included. The two genera never appeared together in the resulting cladograms, even though the position of Stephanomeria was very unstable. In Jansen et al.'s (1991) analysis of chloroplast DNA restriction site variation in the subtribe Microseridinae, Stephanomeria was included and appeared as nested within that subtribe. Stebbins's Malacothrix group is described here as a new subtribe Malacothricinae, separate from the Stephanomeriinae and the Microseridinae.

The Launaea-Sonchus group of Stebbins (1953) comprises two entities, Launaea with the related genera Aetheorhiza (Rechinger, 1974) and Reichardia (Gallego et al., 1980), and the Sonchus group of closely related genera (Actites, Babcockia, Embergeria, Kirkianella, Lactucosonchus, Sonchus, Sventenia, Taeckholmia; cf. Boulos, 1972, 1973, 1974a, b; Aldridge, 1976a, b; Lander, 1976). Many Launaea species share the compressed, nonbeaked fruits and the dimorphic pappus, consisting of intermixed bristles and fine hairs, typical of Sonchus. Hence it appears that the two subgroups are closely related and that the entire Launaea-Sonchus group is monophyletic. It has a scattered but very wide distribution with many Sonchus and Launaea species in Eurasia and throughout Africa. Several genera and species are restricted to the Canary Islands (Babcockia, Lactucosonchus, Sventenia, Taeckholmia); others occur exclusively in Australia (Actites) and New Zealand (Embergeria, Kirkianella). Stebbins included the Launaea-Sonchus group in his Crepidinae sensu lato, a highly polyphyletic taxon. The Crepidinae will be reclassified into four subtribes (Bremer, in press), Crepidinae sensu stricto, Hieraciinae, Lactucinae, and Sonchinae. In the cladistic analysis (Bremer, in press) Sonchus never grouped with the genera representing the three other subtribes. The Sonchinae are described here as a new subtribe.

Catananchinae K. Bremer, subtribus nov. TYPE: Catananche $\mathrm{L}$.

Herbae annuae vel perennes. Bracteae involucri margine plus minusve scariosae. Receptaculum setosum vel paleaceum. Cypselae teretes vel subangulatae et obconicae, ecostatae, erostratae. Pappus e squamis ovato-lanceolatis, apice plerumque in setam scabrido-barbellatam prolongatis, constatus.

Annual or perennial herbs. Involucral bracts with \pm scarious margins. Receptacle setose or paleate. Cypselas terete or subangular and obconical, without ribs and without beak. Pappus of ovate-lanceolate scales apically often prolonged into scabrid-barbellate bristles.

Mediterranean, eight species in three genera: $\mathrm{Ca}$ tananche L., Hymenonema Cassini, Rothmaleria Font Quer.

Malacothricinae K. Bremer, subtribus nov. TYPE: Malacothrix DC.

Herbae annuae vel interdum perennes. Bracteae involucri margine plerumque scariosae. Receptaculum vulgo squamosum, raro paleaceum. Cypselae tereti-fusiformes vel obovoideae, costatae, interdum rostratae. Pappus e setis tenuibus scabridis vel raro plumosis constatus vel raro nullus, extra saepe coronam minutam ferens.

Annual or sometimes perennial herbs. Involucral bracts often with scarious margins. Receptacle generally squamose, rarely paleate. Cypselas teretefusiform or obovoid, ribbed, sometimes beaked. Pappus of slender, scabrid or rarely plumose bristles, or rarely absent, often surrounded by a minute corona.

North American, 33 species in 7 genera: Anisocoma Torrey \& A. Gray, Atrichoseris A. Gray, Calycoseris A. Gray, Glyptopleura Eaton, Malacothrix DC., Munzothamnus P. H. Raven, Pinaropappus Lessing.

Sonchinae K. Bremer, subtribus nov. TYPE: Sonchus L.

Herbae annuae vel perennes, suffrutices vel frutices. Bracteae involucri herbaceae, interdum margine scariosae. Receptaculum nudum. Cypselae plus minusve compressae, ellipsoideo-fusiformes vel oblongo-obovoideae, leviter costatae, laeves vel rugulosae vel valde rugosae, interdum apice attenuatae, erostratae vel rarissime breviter rostratae. Pappus e setis scabrido-barbellatis vel saepe dimorphus e setis et pilis tenuibus mixtis constatus.

Annual or perennial herbs, subshrubs, or shrubs. Involucral bracts herbaceous, sometimes with scarious margins. Receptacle naked. Cypselas \pm compressed, ellipsoid-fusiform or oblong-obovoid, slightly ribbed, smooth or rugulose to strongly rugose, sometimes attenuate apically, without beak or very rarely with a short beak. Pappus of scabrid-barbellate bristles or dimorphic of intermixed bristles and fine hairs.

Almost worldwide, mainly Eurasia and Africa, Canary Islands, also North America, Australia, and New Zealand, ca. 130 species in 11 genera: Actites Lander, Aetheorhiza Cassini, Babcockia Boulos, Embergeria Boulos, Kirkianella Allan, Lactucosonchus (Schultz Bipontinus) Sventenius, Launaea Cassini, Reichardia Roth, Sonchus L., Sventenia Font Quer, Taeckholmia Boulos. 
Acknowledgments. I thank Mats Thulin and one anonymous reviewer for checking the manuscript. The study was supported by a Swedish Natural Science Research Council grant for Asteraceae evolution.

\section{Literature Cited}

Aldridge, A. E. 1976a. A critical reappraisal of the Macaronesian Sonchus subgenus Dendrosonchus s.l. (Compositae-Lactuceae). Bot. Macaronés., IV Ci. 2: $25-58$.

1976b. Macaronesian Sonchus subgenus Dendrosonchus s.l. (Compositae-Lactuceae) including a reappraisal of the species concept and new combinations. Bot. Macaronés., IV Ci. 2: 81-93.

Boulos, L. 1972. Revision systématique du genre Sonchus L. s.l., I: Introduction et classification. Bot. Not. 125: 287-305.

. 1973. Revision systématique du genre Sonchus L. s.l., IV: Sous-genre 1, Sonchus. Bot. Not. 126: 155-196.

. 1974a. Revision systématique du genre Sonchus L. s.l., V: Sous-genre 2, Dendrosonchus. Bot. Not. 127: 7-37.

- 1974b. Revision systématique du genre Sonchus L. s.l., VI: Sous-genre 3, Origosonchus: Genres
Embergeria, Babcockia et Taeckholmia. Bot. Not. 127: 402-451.

Bremer, K. In press. Asteraceae-Cladistics and classification. Timber Press, Portland, Oregon. [Anticipated 1994.]

Gallego, M. J., S. Talavera \& S. Silvestre. 1980. Revisión del género Reichardia Roth. (Compositae). Lagascalia 9: 159-217.

Jansen, R. K., R. S. Wallace, K.-J. Kim \& K. L. Chambers. 1991. Systematic implications of chloroplast DNA variation in the subtribe Microseridinae (Asteraceae: Lactuceae). Amer. J. Bot. 78: 1015-1027.

Jeffrey, C. 1966. Notes on Compositae, I: The Cichorieae in East Tropical Africa. Kew Bull. 18: 427486.

Lander, N. S. 1976. Actites, a new genus of Compositae from Australia. Telopea 1: 129-135.

Raven, P. H. 1963. A flora of San Clemente Island, California. Aliso 5: 289-347.

Rechinger, K. H. 1974. Aetheorrhiza bulbosa (L.) Cass. und ihre geographischen rassen. Phyton (Horn) 16: $211-220$.

Solbrig, O. T. 1963. Subfamilial nomenclature of Compositae. Taxon 12: 229-235.

Stebbins, G. L. 1953. A new classification of the tribe Cichorieae, family Compositae. Madroño 12: 65-81.

Williams, E. W. 1957. The genus Malacothrix (Compositae). Amer. Midl. Naturalist 58: 494-512. 


\section{$2 \mathrm{BHL}$ Biodiversity Heritage Library}

Bremer,

$\mathrm{Ka}$

re. 1993. "New subtribes of the Lactuceae (Asteraceae)." Novon a journal of botanical nomenclature from the Missouri Botanical Garden 3, 328-330.

https://doi.org/10.2307/3391378.

View This Item Online: https://www.biodiversitylibrary.org/item/14663

DOI: https://doi.org/10.2307/3391378

Permalink: https://www.biodiversitylibrary.org/partpdf/23659

\section{Holding Institution}

Missouri Botanical Garden, Peter H. Raven Library

\section{Sponsored by}

Missouri Botanical Garden

\section{Copyright \& Reuse}

Copyright Status: In copyright. Digitized with the permission of the rights holder.

License: http://creativecommons.org/licenses/by-nc-sa/3.0/

Rights: https://biodiversitylibrary.org/permissions

This document was created from content at the Biodiversity Heritage Library, the world's largest open access digital library for biodiversity literature and archives. Visit BHL at https://www.biodiversitylibrary.org. 